\title{
Synthesis, Spectroscopic and Antibacterial Studies of Zinc(II) Complexes Derived from Salicylaldehyde, Leucylalanine and Glycylglycine
}

\author{
Muayed Ahmed Redayan*
}

Received 6, July, 2011

Accepted 19, November, 2011

\begin{abstract}
:
Two Schiff base ligands $\mathrm{L}_{1}$ and $\mathrm{L}_{2}$ have been obtained by condensation of salicylaldehyde respectively with leucylalanine and glycylglycine then their complexes with $\mathrm{Zn}$ (II)were prepared and characterized by elemental analyses , conductivity measurement, IR and UV-Vis .The molar conductance measurement indicated that the $\mathrm{Zn}(\mathrm{II})$ complexes are 1:1 non-electrolytes. The IR data demonstrated that the tetradentate binding of the ligands $L_{1}$ and $L_{2}$. The in vitro biological screening effect of the investigated compounds have been tested against the bacterial species Staphlococcus aureus, Escherichia coil , Klebsiella pneumaniae, Proteus vulgaris and Pseudomonas aeruginosa by the disc diffusion method. A comparative study of inhibition values of the Schiff base ligands and their complexes indicated that the complexes exhibit higher antimicrobial activity than the free ligands . Zinc ions are proven to be essential for the growth-inhibitor effect. The extent of inhibition appeared to be strongly dependent on the initial cell density and on the growth medium .
\end{abstract}

\section{Key words: Dipeptide, Schiff base, Antibacterial, Zn(II )complexes}

\section{Introduction:}

The coordination chemistry of amino acid Schiff base is of considerable interest due to their biological importance[1,2]. However, little attention has been paid to systems in which the Schiff bases derived from simple peptides. A vanadium complex $\mathrm{VO}($ sal-glygly $)\left(\mathrm{H}_{2} \mathrm{O}\right)_{\mathrm{n}}($ sal-glygly $=\mathrm{N}-$ salicylideneglycylglycine); $\mathrm{n}=1.5-3.0$ has been isolated from relatively concentrated solutions containing oxovandium (IV), glycylglycine and salicylaldehyde [3].Synthesis ,crystal structure and magnetic studies of cisconfiguration copper (II ) - M(II ) (M= $\mathrm{Ba}, \mathrm{Ca}$ ) complexes of the sal - glygly Schiff base have been determined [4] . Sallam and coworkers have been prepared and characterized the uranyl complexes of Schiff base obtained by condensing glygly with hydroxybenzaldehyde [5]. Recently, tow copper (II) tripeptide Schiff base complexes: [ $\mathrm{Mg}\left(\mathrm{H}_{2} \mathrm{O}\right][\mathrm{CuL}] 2.3 .5 \mathrm{H}_{2} \mathrm{O}$ and $\left[\mathrm{Cd}\left(\mathrm{H}_{2} \mathrm{O}\right)_{4}(\mathrm{CuL})_{2}\right] .3 .5 \mathrm{H}_{2} \mathrm{O} \quad\left(\mathrm{H}_{3} \mathrm{~L}=\right.$ $\mathrm{N}$-sal-glygly) have been synthesized and structurally characterized [6]. Also, Binuclear copper, nickel and cobalt of the Schiff bases have been prepared by condensation of glycylglycine with acetylacetone, benzoylacetone, dibenzoylmethane and thenoyltrifluoroacetone[7]. Many metals complexes have powerful antimicrobial activities and are already common day-to-day use in medicinal field such as silver bandages for treatment of burns ,zinc antiseptic creams, bismuth drugs for the treatment of ulcers and metal clusters

*Department of Chemistry / College of Education- Al- Razi / Diayla University 
as anti-HIV drugs. The potential for further development of metal-based drugs and treatment as an antimicrobial agent $[8,9]$ is enormous and also of great importance with the evolution of drug-resistant bacteria and threats from a range of viral diseases. The discovery and development of antibiotics are among the most powerful and successful achievements of modern science and technology for the control of infectious diseases. Metal-based drugs represent a novel group of anti fungal agents with potential applications for the control of fungal infection. This inspires synthetic chemists to search for new metal complexes for bioactive compounds and zinc in particular has attracted the researchers. The field of macrocyclic chemistry of metals is developing very rapidly because of its application and importance in the area of coordination chemistry [10] .The finding that the tetrahedral zinc complexes in its cavities generally represent the optimal, least strained structures among various zinc polyhedra may explain why fourcoordinate zinc is chosen to play a structural role in zinc fingers and enzymes. Recently, Nair and coworkers have been synthesized and characterized some Schiff base metal complexes and their in vitro antimicrobial activities have been investigated [11,12]. In the present paper, I report the result on the synthesis, characterization and antimicrobial activities of $\mathrm{Zn}$ (II) complexes of Schiff base ligands L1 and L2 derived from silicylaldehyde and leucylalanine and glycylglycine respectively.

\section{Materials and Methods : Reagents and apparatus.}

The dipeptide, leucylalanine and glycylglycine has been purchased from Fluka (LTD) and used without further purification .Salicylaldehyde have been obtained from Fluka and $\mathrm{Zn}$ (II) acetate was obtained from Merck (LTD) .All other reagent and solvent have been purchased from commercial sources and were of analytical grade. Solvent have been purified and dried by standard methods. Elemental analysis was done using a PerkinElmer elemental analyzer .IR spectra have been recorded in $\mathrm{KBr}$ disc on a (8300) (FT-IR) Shimadzu spectrophotometer in the range 4000$400 \mathrm{~cm}^{-1}$ region. The electronic spectra have been recorded on a Shimadzu,160, using a quartz cell of (1.0) $\mathrm{cm}$ length spectrophotometer .Molar conductance of the complexes has been measured in DMSO $\left(10^{-3} \mathrm{M}\right)$ solution using a coronation digital conductivity meter.

In vitro antimicrobial activity. Antibacterial activity of the ligands and their complexes have been tested against the bacterial species Staphlococcus aureus, Escherichia coil, Klebsiella pneumaniae, Proteus vulgaris and Pseudomonas aeruginosa by Kirby bauer Disc diffusion method [13]. Amikacin, Ofloxacine and Ciprofloxacine have been used as the standard antibacterial agent .The test organisms were grown on nutrient agar medium in petri plates. The compounds have been prepared in DMSO and soaked in filter paper disc of $5 \mathrm{~mm}$ diameter and $1 \mathrm{~mm}$ thickness .The disc were placed on the previously seeded plates and incubated at $37 \mathrm{C}^{\circ}$ and the diameter inhibition zone [14] around each disc has been measured after $24 \mathrm{~h}$ for bacteria .

Synthesis of the Dipeptide Schiff base Potassium Salt. A solution containing (1.01 gm, 5mmol) of leucylalanine and $(0.66 \mathrm{gm}, 5 \mathrm{mmol})$ of glycylglycine in $20 \mathrm{ml}$ of water was added to $15 \mathrm{~mL}$ of an ethanol solution containing (0.36 gm ,5 mmol) of $\mathrm{KOH}$. The resulting solution was 
stirred on a water bath at $25 \mathrm{C}^{\circ}$ for half an hour and then filtered. The filtrate was added dropwise to $20 \mathrm{~mL}$ of an ethanol solution of Salicylaldehyde (0.61 gm , $5 \mathrm{mmol})$ with stirring on a water bath at $25 \mathrm{C}^{\circ}$ for one hour. The volume of the solution was reduced by distillation to $5 \mathrm{~mL}$ and then ethanol $(10 \mathrm{~mL})$ was added. The yellowish precipitate formed was separated by filtration . The precipitate was recrystalled from methanol . [15]

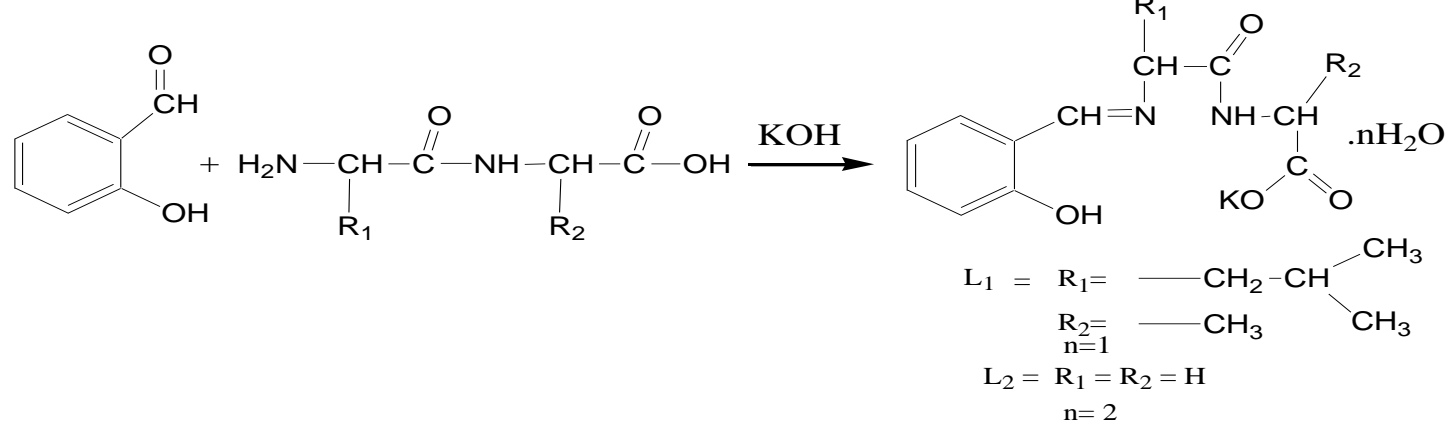

Fig.1 Synthesies and structures of ligands

Synthesis of $\mathrm{Zn}$ (II ) Schiff base complexes. The Zinc acetate (1.09 gm , $5 \mathrm{mmol}$ ) was dissolved in $20 \mathrm{~mL}$ of water. The solution was filtered and added dropwise into $25 \mathrm{~mL}$ of an ethanol solution of the Schiff base ligands $\quad(1.81$ and $1.55 \mathrm{gm}$ .respectively ,5mmol). The reaction mixture was stirred at $25 \mathrm{C}^{\circ}$ on water bath for $3 \mathrm{~h}$. The resulting precipitate has been filtered, washed with ethanol and diethyl ether ,then recrystallized from methanol, and dried in vacuum desiccator .[15] The analytical data are summarized in Table 1.

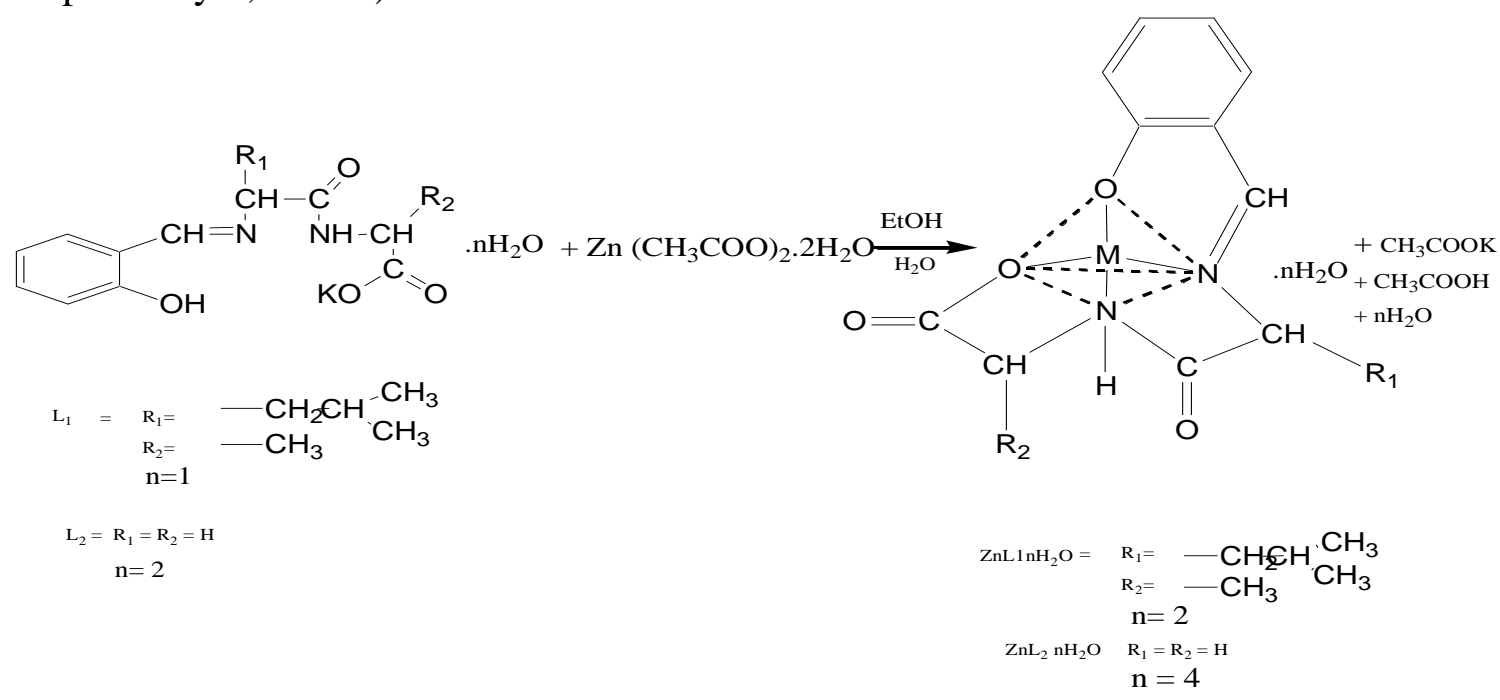

Fig.2 Synthesies and proposed structure for $\mathrm{ZnL}_{1}$ and $\mathrm{ZnL}_{2}$ Schiffbase complexes

\section{Results and Discussion:}

$\mathrm{Zn}$ (II) complexes are stable at room temperature, insoluble in water but soluble in DMF and DMSO. The physical properties and analytical data of the ligands and their complexes are given in Table 1. Elemental analysis data of the complexes are in good agreement with theoretical values. The analytical data (Table 1) indicate that the metal to ligand ratio is $1: 1$ in all the complexes systems and it can be represented as $\left[\mathrm{ZnL}_{1}\right]$. $\mathrm{nH}_{2} \mathrm{O}$ and [ $\left.\mathrm{ZnL}_{2}\right] \cdot \mathrm{nH}_{2} \mathrm{O}$, where $\mathrm{L}_{1}$ and $\mathrm{L}_{2}$ are 
Schiff base ligands obtained by the condensation of salicylaldehyde respectively with leucylalanine and glycylglycine. The values of the conductivities of the $\mathrm{Zn}$ (II) complexes are in the $(7.2-12.5) \Omega^{-1} \mathrm{~mol}^{-1} \mathrm{~cm}^{2}$ range, indicating that the proposed complexes are 1:1 non-electrolytes [16].

Table 1. Physical and analytical data of the Schiff base ligands and their complexes

\begin{tabular}{|c|c|c|c|c|c|c|c|c|c|}
\hline \multirow{2}{*}{ Compound } & \multirow{2}{*}{ Formula } & \multirow{2}{*}{$\begin{array}{c}\text { Mol. } \\
\text { Wt. } \\
\text { gm/mol }\end{array}$} & \multirow{2}{*}{$\begin{array}{l}\text { M.p } \\
\left(\mathrm{C}^{\circ}\right)\end{array}$} & \multirow{2}{*}{$\begin{array}{l}\text { Yield } \\
(\%)\end{array}$} & \multirow{2}{*}{$\begin{array}{c}\text { Conductivity } \\
\mathrm{Ohm}^{-1} \\
\mathrm{~cm}^{2} \mathrm{~mol}^{-1}\end{array}$} & \multicolumn{4}{|c|}{ Found (calc.) (\%) } \\
\hline & & & & & & $\mathrm{C}$ & $\mathrm{H}$ & $\mathrm{N}$ & M \\
\hline $\mathrm{KHL}_{1} \cdot \mathrm{H}_{2} \mathrm{O}$ & $\mathrm{C}_{16} \mathrm{H}_{23} \mathrm{KN}_{2} \mathrm{O}_{5}$ & 362.46 & 134 & 35 & - & $\begin{array}{c}53.09 \\
(53.02)\end{array}$ & $\begin{array}{c}6.31 \\
(6.40) \\
\end{array}$ & $\begin{array}{c}8.01 \\
(7.73) \\
\end{array}$ & - \\
\hline $\mathrm{KHL}_{2} \cdot 2 \mathrm{H}_{2} \mathrm{O}$ & $\mathrm{C}_{11} \mathrm{H}_{15} \mathrm{KN}_{2} \mathrm{O}_{6}$ & 310.06 & 120 & 38 & - & $\begin{array}{c}42.79 \\
(42.57)\end{array}$ & $\begin{array}{c}4.97 \\
(4.87)\end{array}$ & $\begin{array}{c}9.43 \\
(9.03)\end{array}$ & - \\
\hline $\mathrm{ZnL}_{1} \cdot 2 \mathrm{H}_{2} \mathrm{O}$ & $\mathrm{C}_{16} \mathrm{H}_{24} \mathrm{~N}_{2} \mathrm{O}_{6} \mathrm{Zn}$ & 405.78 & $>265$ & 68 & 7.2 & $\begin{array}{c}47.44 \\
(47.36)\end{array}$ & $\begin{array}{c}5.88 \\
(5.96) \\
\end{array}$ & $\begin{array}{c}7.29 \\
(6.90) \\
\end{array}$ & $\begin{array}{c}16.24 \\
(16.12)\end{array}$ \\
\hline $\mathrm{ZnL}_{2} \cdot 4 \mathrm{H}_{2} \mathrm{O}$ & $\mathrm{C}_{11} \mathrm{H}_{18} \mathrm{~N}_{2} \mathrm{O}_{8} \mathrm{Zn}$ & 371.68 & $>250$ & 65 & 12.5 & $\begin{array}{c}35.40 \\
(35.55)\end{array}$ & $\begin{array}{c}4.53 \\
(4.88)\end{array}$ & $\begin{array}{c}7.66 \\
(7.54)\end{array}$ & $\begin{array}{c}17.44 \\
(17.60)\end{array}$ \\
\hline
\end{tabular}

IR spectra. The Schiff base ligands $\mathrm{L}_{1}$ and $\mathrm{L}_{2}$ show $(\mathrm{C}=\mathrm{N})$ azomethine bands observed at $1618 \mathrm{~cm}^{-1}$ and $1615 \mathrm{~cm}^{-1}$ respectively . On complexation, this band was shifted to $1610 \mathrm{~cm}^{-1}$ and $1600 \mathrm{~cm}^{-1}$ regions [17 ] due to the coordination of azomethine nitrogen to the $\mathrm{Zn}$ (II ) ion. In the spectra of Schiff base ligands, the peptide bands were observed at $1521 \mathrm{~cm}^{-1}$ and 1518 $\mathrm{cm}^{-1}$. On complexation, this band was shifted to $1525 \mathrm{~cm}^{-1}$ and $1525 \mathrm{~cm}^{-1}$ region, indicating the linkage between metal ion and the peptide nitrogen atoms. The asymmetric carboxyl stretching $v_{\text {asy }}\left(\mathrm{COO}^{-}\right)$was shifted to higher and lower frequency in the $1600 \mathrm{~cm}^{-1}$ and $1560 \mathrm{~cm}^{-1}$ range and the symmetric carboxyl stretching $v_{\text {sym }}\left(\mathrm{COO}^{-}\right)$was shifted to higher and lower frequency in the $1520 \mathrm{~cm}^{-1}$ and 1440 range, indicating the linkage between the metal ion and carboxylato oxygen atom.The asymmetric and symmetric stretching vibration of the carboxylato group in the complexes shows the separation value $(\Delta v)$ greater than $150 \mathrm{~cm}^{-1}$.This indicates monodentate binding of carboxylato group in Zinc (II) complexes. Furthermore, the presence of coordinated and lattice water molecules appeared respectively at 3375 and $3380 \mathrm{~cm}^{-1}$ in $\mathrm{ZnL}_{1}$ and $\mathrm{ZnL}_{2}$ complexes may be attributed to $\mathrm{O}-\mathrm{H}$ stretching vibration. The appearance of two bands at 510 and $520 \mathrm{~cm}^{-1}$ corresponds to $v(\mathrm{M}-\mathrm{O})$ and the bands at 430 and $425 \mathrm{~cm}^{-1}$ corresponds to $v$ (M-N) stretching vibrations respectively (see Fig 3) . Thus, the IR spectral data indicate that $\mathrm{ZnL}_{1}$ and $\mathrm{ZnL}_{2}$ complexes tetradentate binding through azomethine nitrogen, amide nitrogen, phenolic oxygen and carboxylato oxygen atoms. The IR data are summarized in Table 2

Table.2. Important IR Absorption Bands $\left(\mathrm{cm}^{-1}\right)$ of the Schiff base ligands and their complexes

\begin{tabular}{|c|c|c|c|c|c|c|c|c|c|c|}
\hline Compound & $\mathrm{vOH}$ & $v \mathrm{C}=\mathrm{N}$ & $\mathrm{v}_{\mathrm{as}} \mathrm{COO}^{-}$ & $v(\mathrm{CONH})$ & $\mathrm{v}_{\mathrm{sym}} \mathrm{COO}^{-}$ & vC-N & vC-O & $\delta \mathrm{coo}^{-}$ & vM-O & vM-N \\
\hline $\mathrm{KHL}_{1} \cdot \mathrm{H}_{2} \mathrm{O}$ & 3380 & 1618 & $\begin{array}{c}1598 \\
\mathrm{~s}\end{array}$ & $\begin{array}{c}1521 \\
S\end{array}$ & $\begin{array}{c}1460 \\
\mathrm{~m}\end{array}$ & $\begin{array}{c}1398 \\
s\end{array}$ & 1240 & 765 & & - \\
\hline $\mathrm{KHL}_{2} .2 \mathrm{H}_{2} \mathrm{O}$ & $\begin{array}{c}3385 \\
\text { s,br }\end{array}$ & $\begin{array}{c}1615 \\
\mathrm{~s}\end{array}$ & $\begin{array}{c}1600 \\
\mathrm{~m}\end{array}$ & $\begin{array}{c}1518 \\
\mathrm{~S}\end{array}$ & $\begin{array}{c}1450 \\
\mathrm{~m}\end{array}$ & $\begin{array}{c}1395 \\
\mathrm{~s}\end{array}$ & $\begin{array}{c}1245 \\
\text { W }\end{array}$ & $\begin{array}{c}765 \\
s\end{array}$ & - & - \\
\hline $\mathrm{ZnL}_{1} \cdot 2 \mathrm{H}_{2} \mathrm{O}$ & 3375 & 1610 & 1600 & $\begin{array}{c}1525 \\
\mathrm{~m}\end{array}$ & $\begin{array}{c}1520 \\
\mathrm{~m}\end{array}$ & $\begin{array}{c}1390 \\
\mathrm{~m}\end{array}$ & 1160 & $\begin{array}{c}755 \\
\mathrm{~s}\end{array}$ & 430 & 510 \\
\hline $\mathrm{ZnL}_{2} \cdot 4 \mathrm{H}_{2} \mathrm{O}$ & $\begin{array}{c}3380 \\
\text { s,br }\end{array}$ & $\begin{array}{c}\mathrm{s} \\
\mathrm{s}\end{array}$ & $\begin{array}{c}1560 \\
\mathrm{~s}\end{array}$ & 1523 & 1442 & 1380 & $\begin{array}{c}1242 \\
\mathrm{~m}\end{array}$ & $\begin{array}{c}768 \\
\mathrm{~m}\end{array}$ & $\begin{array}{c}425 \\
w\end{array}$ & 520 \\
\hline
\end{tabular}


UV/Vis. Spectra. The Schiff base ligands L1 and L2 show the absorption bands at $291 \mathrm{~nm}$ and $280 \mathrm{~nm}$, which is assigned to $\pi-\pi^{*}$ transition of the $\mathrm{C}=\mathrm{N}$ chromophore. On complexation , this band was shifted to lower wavelength region $285 \mathrm{~nm}$ and $275 \mathrm{~nm}$, suggesting the coordination of azomethine nitrogen with $\mathrm{Zn}$ (II) ion [18](see Fig 4) . Zn(II) complex does not exhibit d-d electronic transition due to the completely filled ( d) orbital. Four coordinate $\mathrm{Zn}$ (II)complexes would have tetrahedral geometry (Fig.2) .

Antimicrobial activity. The in vitro biological screening effect of the investigated compounds were tested against some bacterial species(isolated from patients) by the disc diffusion method . The results of the antibacterial activities were given in Table 2. The results show that both the
Schiff base ligands have moderate activity in the antibacterial species. Against all organisms, $\mathrm{ZnL}_{1}$ and $\mathrm{ZnL}_{2}$ complexes were found to be highly active in the bacterial species of $S$. aureus, E. coil and $P$. aeruginosa . However, $\mathrm{ZnL}_{1}$ has moderate activity in the species of $K$. penunaniae. Moreover, the results point out that in P.vulgaris, $\mathrm{ZnL}_{1}$ complex is less active and $\mathrm{ZnL}_{2}$ is moderately active . Again, the comparison of the above results with Amikacin, Ofloxacine and Ciprofloxacine antibacterial standards demonstrates that $S$. aureus, $K$. penunaniae, P.vulgaris and $P$. aeruginosa are moderately active. However, the standards Amikacin and Ciprofloxacine show higher activity in the E. coil species, while Ofloxacine is less active in the $P$. aeruginosa species . Table 3.

Table 3. Antibacterial activity of Schiff base ligands and their complexes

\begin{tabular}{|c|c|c|c|c|c|}
\hline \multirow{2}{*}{ Compound } & Gram positive bacteria & \multicolumn{4}{|c|}{ Gram negative bacteria } \\
\cline { 2 - 6 } & S. aureus & K. penunaniae & P.vulgaris & E. coil & P. aeruginosa \\
\hline $\mathrm{KHL}_{1} \cdot \mathrm{H}_{2} \mathrm{O}$ & ++ & ++ & ++ & ++ & ++ \\
\hline $\mathrm{KHL}_{2} \cdot 2 \mathrm{H}_{2} \mathrm{O}$ & ++ & ++ & ++ & ++ & ++ \\
\hline $\mathrm{ZnL}_{1} \cdot 2 \mathrm{H}_{2} \mathrm{O}$ & +++ & ++ & + & +++ & +++ \\
\hline $\mathrm{ZnL}_{2} \cdot 4 \mathrm{H}_{2} \mathrm{O}$ & +++ & +++ & ++ & +++ & +++ \\
\hline $\mathrm{Amikacin}^{\mathrm{a}}$ & ++ & ++ & ++ & +++ & ++ \\
\hline Ofloxacin $^{\mathrm{a}}$ & ++ & ++ & ++ & ++ & + \\
\hline Ciprofloxacin & $\mathrm{a}$ & ++ & ++ & +++ & ++ \\
\hline
\end{tabular}

Inhibition values $=0.1-0.5 \mathrm{~cm}$ beyond control $=+$ (less active $)$; inhibition values $=0.6-1.0 \mathrm{~cm}$ beyond control $=$ $++($ moderate active $)$; inhibition values $=1.1-1.5 \mathrm{~cm}$ beyond $\quad$ control $=+++($ highly active $) .{ }^{\text {a Standards. }}$

Mode of action. Although the exact mechanism hasn't been understood biochemically, mode of action of antimicrobils may involve various target in microorganisms.

(i) Interference with the cell wall synthesis, damage as a result of which cell permeability may be altered ( or) they may disorganize the lipoprotein leading to the cell death.

(ii) Deactivate various cellular enzymes, which play a vital role in different metabolic pathways of these microorganisms . (iii) Formation of a hydrogen bond through the azomethine group with the active center of cell constituents, resulting in interference with the normal process.

Effect of azomethine $(\mathrm{C}=\mathrm{N})$ group. The mode of action of the compounds may involve formation of a hydrogen bond through azomethine group $(\mathrm{C}=\mathrm{N})$ with the active centers of cell constituents[19] resulting in interferences with the normal process. 


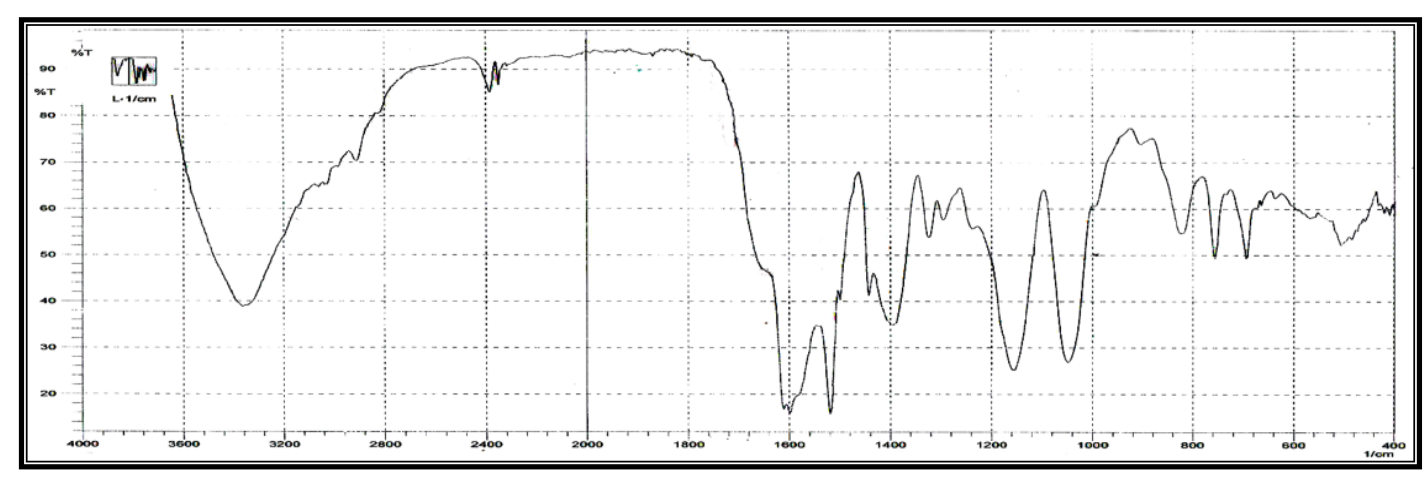

IR spectra of ligand $\mathrm{L}_{1}$
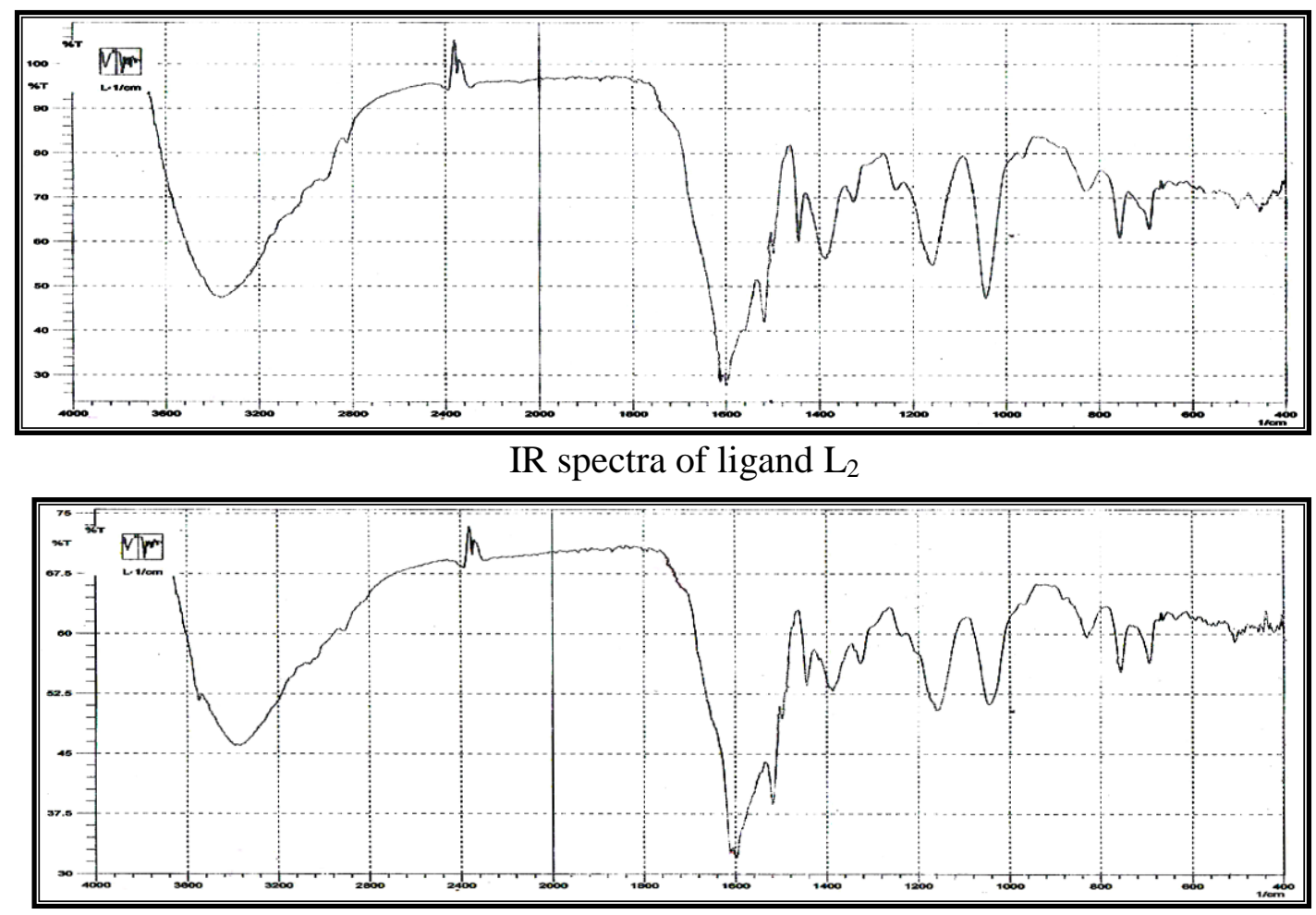

IR spectra of $\mathrm{ZnL}_{1} .2 \mathrm{H}_{2} \mathrm{O}$

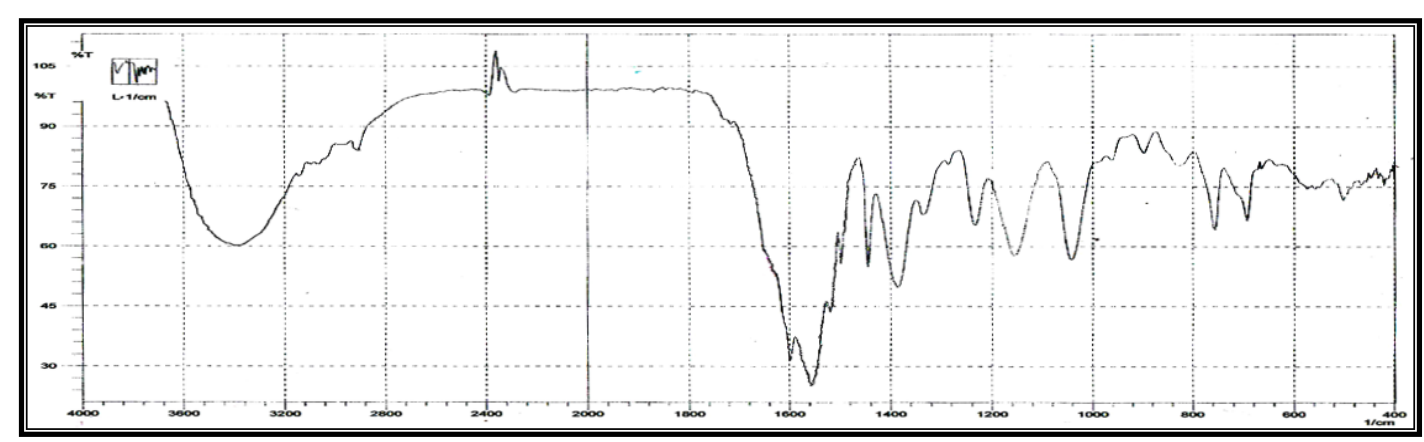

IR spectra of $\mathrm{ZnL}_{2} \cdot 4 \mathrm{H}_{2} \mathrm{O}$

Fig. 3 IR spectra for the prepared compounds 


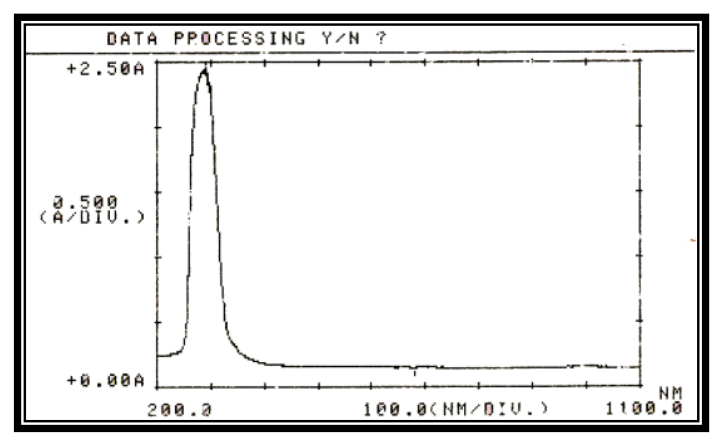

$\mathrm{UV}-\mathrm{Vis}$ of Ligand $\mathrm{L}_{1}$

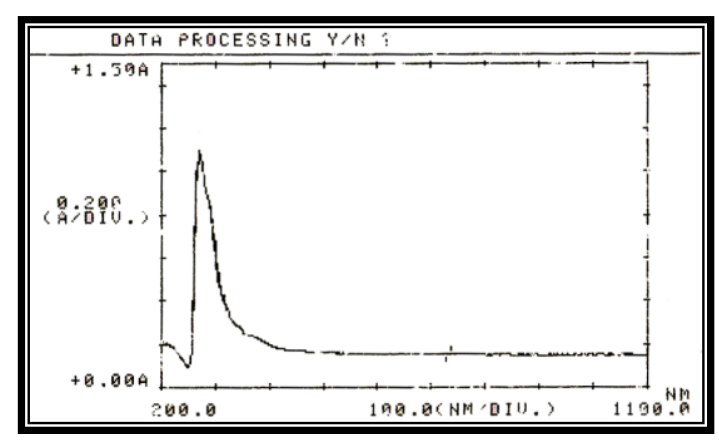

UV-Vis of $\mathrm{ZnL}_{1} \cdot 2 \mathrm{H}_{2} \mathrm{O}$

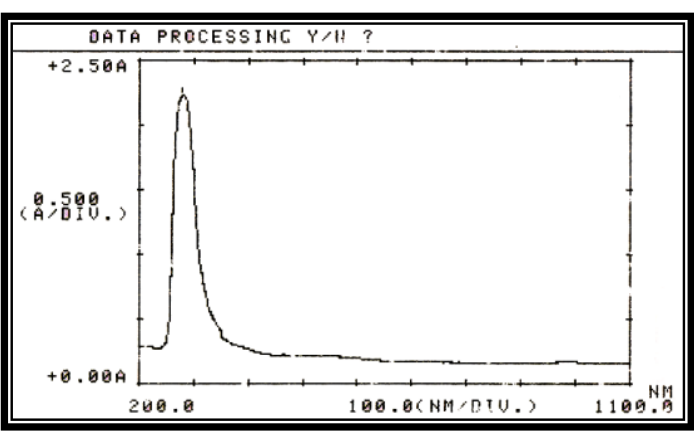

UV-Vis of Ligand $\mathrm{L}_{2}$

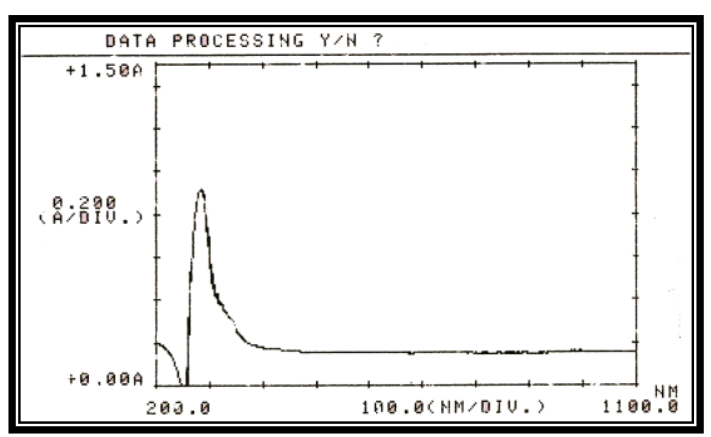

$\mathrm{UV}-\mathrm{Vis}$ of $\mathrm{ZnL}_{2} \cdot 4 \mathrm{H}_{2} \mathrm{O}$

Fig. $4 \mathrm{UV}$-Vis spectra for the prepared compounds

\section{References:}

1. Mathews, I.I. , Joy, P.A. and Vasudevan , S. 1991.Synthetic, spectroscopic, magnetic, and $\mathrm{x}$-ray structural studies on a vitamin $\mathrm{B}_{6}-$ amino acid Schiff base complex, aqua(5-

phosphopyridoxylidenetyrosinato) copper(II) tetrahydrate, Inorg. Chem., 30(9):2181-2185 .

2. Angoso, A., Marin-Lorento, J.M. , Manzano, J.L., Martin, M. , Martin, R. and Rodriguez, E. 1992.Preparation and study of amino acid (DL- leucine, Lisoleucine, L-histidine) Schiff bases with ethyl- $\alpha$ ketocyclopentylcarboxylate and the corresponding copper(II) complexes, Inorg. Chim . Acta, 195(1):45-49 .

3. Costa Pessoa , J., Cavaco , I.; Correia , I., Costa, D., Henriques, R. T. and Gillard , R. D. 2000. Preparation and characterization of new oxovanadium (IV) Schiff base complexes derived from salicylaldehyde and simple dipeptides , Inorg. Chim . Acta, 305(1): 7-13 .

4. Hu, C. J., Ren ,X. M., Lu, C. S., Zou, Y., Zhang, W.W.,Duan C.Y. and Meng, Q.J. 2003.Synthesis ,crystal structure and magnetic studies of cis-configuration copper(II)-M(II) $\quad(\mathrm{M}=\mathrm{Ba} \quad$,Ca) complexes of novel Schiff bases derived from salicylaldehyde and dipeptides ,Transition Met. Chem. , 28(3):350-355.

5. Sallam ,Sh.A. and Ayad, M.I. 2003. Spectral and thermal properties of some uranyl complexes of some Schiff bases derived from glycylglycine, J. Kor. Chem. Soc., 47(3):199- 205 .

6. Liu , W.L., Zou, Y., Ni, C.L.,Ni, Z.P., Li, Y.Z., Yao, Y.G. and Meng, Q.J. 2004. Synthesis and characterization of copper (II) 
Schiff base complexes derived from salicylaldehyde and glycylglycylglycine, Polyhedron, 23(5): 849-855.

7. Sallam, Sh.A. 2006. Binuclear copper (II), nickel (II) and cobalt (II) complexes with $\mathrm{N}_{2} \mathrm{O}_{2}$ chromophores of glycylglycine Schiff bases of acetylacetone, benzoylacetone and thionyltrifluoroacetone

Transition Met. Chem. ,31(1):4655.

8. Scozzafava, A., Menabuoni, L., and Mincione, F. 2001. Carbonic anhydrase inhibitors:Synthesis of sulfonamides incorporating dtpa tails and of their zinc complexes with powerful topical antiglaucoma properties , Bioorg. Med. Chem. Lett., 11(4):575-582.

9. Scozzafava, A. and Supuran, C. 2000.Carbonic anhydrase and matrixmetalloproteinase inhibitors: Sulfonylated amino acid hydroxamates with MMP inhibitory properties act as efficient inhibitors of CA isozymes I,II, and IV, and N-hydroysulfonamides inhibit both these zinc enzymes , J. Med. Chem., 43(20):3677-3687.

10. Ashu, C., Nidhi, B., Gajraj, A. and Singh , R. 2003. Antifertility, antibacterial ,antifungal and perecent disease incidence aspects of macrocyclic complexes of Mn(II), J. Inorg. Bio-chem., 96(23) :393-400 .

11. Nair, M. S. and Raj, C. R. S. 2007. Furfuraldenevalinate system: Solution chemistry of denticity reduction, gas and solid phase complexing behavior, J. Mol. Liquids , 131-133:196-199

12. Nair, M. S., Sudhakumari, S. and Neelakantan, M. A, 2007. Studies on some novel Schiff base complexes in solution and solid phase, J. Coord. Chem. 60(12):1291-1303.

13.Bauer, A. W., Kirby, W. M. M. , Sherries, J. C. and Truck, M. 1996. Antibiotic susceptibility testing by a standardized single disk method, Am. J. Clin. Pathol. 45(3):493-496.

14. Ferrari, M. B., Capacchi, S., Reffo, G , Tarasconi, P., Albertini, R., Pinelli, S. and Lunghi, P. 1999. Synthesis structural characterization and biological activity of helicin thiosemicarbazone momnohydrate and a $\mathrm{Cu}$ (II) complex of salicylaldehyde thiosemicarbazone, Inorg. Chim. Acta,286(2):134-141.

15. Wang, G. 2000. Synthesis and characterization of novel complexes of a dipeptide Schiff base ligand containing DL- alanylDL- alane, Synth. React. Inorg. Met-Org. Chem., 30(4):601-608.

16. Geary ,W. J. 1971. The use of conductivity measurements in organic solvents for the characterization of coordination compounds , Coord. Chem. Rev. ,7(1):81-122.

17. Nakamoto, K. 1992. Infra-red and Raman Spectra of Inorganic and Coordination Compounds, John Wiley and Sons, New York , $3^{\text {rd }}$ Ed, pp. 91-112.

18. Lever, A. B. P. 1984. Inorganic Electronic Spectroscopy, Elsevier, $2^{\text {nd }}$ Ed , Amsterdam, pp.77-85.

19. Mishra, L. and Sing ,V. K. 1993. Synthesis , structural and antifungal studies of $\mathrm{Co}$ (II), $\mathrm{Ni}$ (II) , $\mathrm{Cu}(\mathrm{II})$ and $\mathrm{Zn}$ (II) complexes with Schiff bases bearing benzimidazoles, Indian J. Chem. ,32A:440- 449 . 


\section{تحضير ودراسة طيفية وبكتيرية لمعقدات الزنك الثنائية والمشتقة من ونائن السالسلايهايد و ليوسيل-الانين و كلايسيلــ كلايسين}

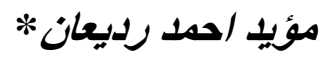

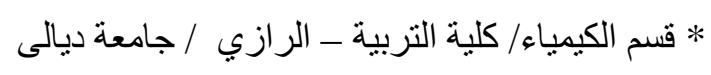

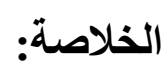

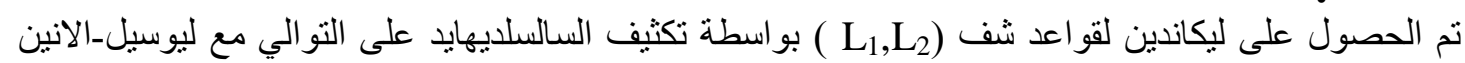

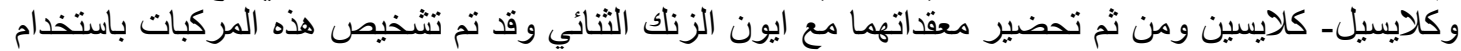

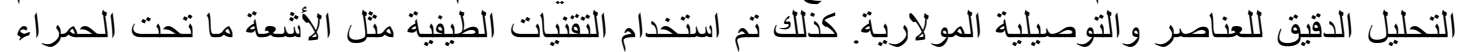

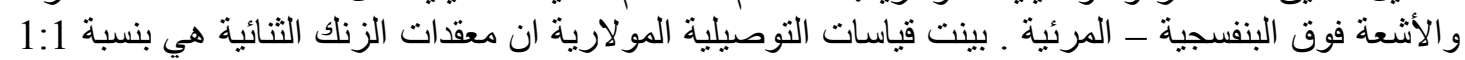

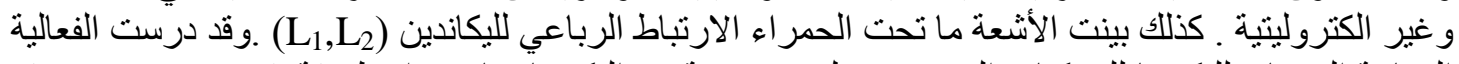

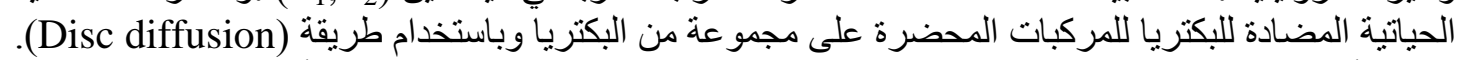

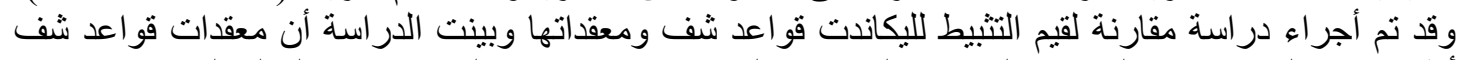

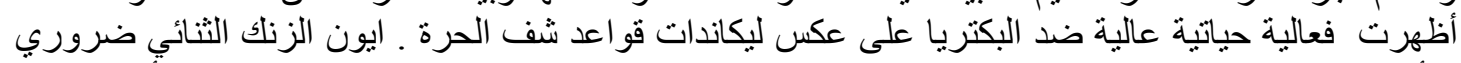

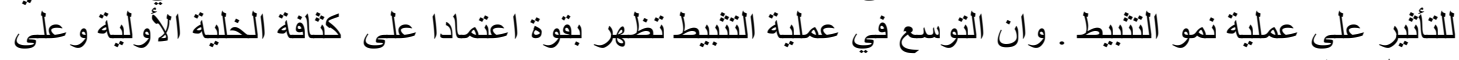

